\title{
A Note on the Effects of the Income Stabilisation Tool on Income Inequality in Agriculture
}

\section{Journal Article}

Author(s):

Finger, Robert (D); El Benni, Nadja

Publication date:

2014-09

Permanent link:

https://doi.org/10.3929/ethz-b-000088667

Rights / license:

In Copyright - Non-Commercial Use Permitted

Originally published in:

Journal of Agricultural Economics 65(3), https://doi.org/10.1111/1477-9552.12069 


\section{Postprint}

This is the accepted version of a paper published in the Journal of Agricultural Economics. This paper has been peer-reviewed but does not include the final publisher proof-corrections or journal pagination.

\section{Citation for the original published paper:}

Finger, R., El Benni, N. (2014). A note on the effects of the Income Stabilisation Tool on income inequality in agriculture. Journal of Agricultural Economics 65(3): 739-745. DOI: $10.1111 / 1477-9552.12069$

Access to the published version may require subscription.

N.B. When citing this work, cite the original published paper. 


\title{
A note on the effects of the Income Stabilisation Tool on income inequality in agriculture
} Robert Finger, Nadja El Benni ${ }^{1}$

\begin{abstract}
Increasing concerns with income risks in agriculture have led to discussions on the introduction of an Income Stabilisation Tool (IST) in Europe. In this note, we extend existing evaluations of the IST by investigating the potential effect of the IST on inequality in farm incomes using Swiss agriculture as a case study. We find that the IST will significantly reduce income inequality, in particular by increasing lower quantiles of the income distribution. This property constitutes a value-added of the IST that is not yet considered in the current policy debate.
\end{abstract}

Keywords: Risk, income stabilization, income inequality, agricultural policy

JEL Classification: Q12, Q18, G22, D63

\section{Introduction}

Managing income risks in agriculture is of particular importance for farmers and policy makers. This has motivated several countries to (or planning to) implement income insurance or income stabilization mechanisms (see Meuwissen et al., 2011, for an overview). This type of whole farm income stabilization instrument has the advantage of providing a single policy covering all production and price risks and their covariates. Furthermore, governmental support to this type of risk management instrument is allowed within the framework of the World Trade Organisation (green box), which has fostered political interest in this measure. However, these instruments may face problems with respect to the establishment of proper income trigger levels, information asymmetries, production distortions as well as discouragement of other risk management instruments (e.g. Meuwissen et al., 2011, Mary et al., 2013, OECD, 2011). Despite these potential issues, the European Union has proposed the introduction of a whole-farm income stabilisation tool (IST) (EC, 2011), which has also received the attention of policy makers in in other countries such as Switzerland (e.g. El Benni, 2012). Research on income

\footnotetext{
${ }^{1}$ RF: University of Bonn, Germany, and Wageningen University, The Netherlands. NEB: University of Applied Sciences, Chur, Switzerland, and ETH Zurich, Switzerland. Contact Author, RF: r.finger@ilr.uni-bonn.de, Meckenheimer Allee 174, 53115 Bonn, Germany.
} 
insurance schemes in agriculture such as the IST has focused on the actuarial evaluation of this instrument, its (governmental) costs, the identification of specific beneficiaries within the farm population and its impacts on optimal farm plans (e.g. dell'Aquila and Cimino, 2012, Pigeon et al., 2012, Liesivaara et al., 2012, Turvey, 2012). Beyond managing income risks, the reduction of income inequality is also on the agenda of agricultural policy, in particular with respect to the maintenance of an adequate standard of living for farmers and the minimization of income disparities (e.g. Keeney, 2000, El Benni and Finger, 2013)². Events causing exceptional income losses (e.g. extreme climate or market events) are expected to increase income inequality among the farm population (e.g. Turvey and Kong, 2010) and there is thus an 'equity rationale' for protection against such events using income stabilization mechanisms (e.g. Alderman and Haque, 2008). An income inequality reducing property may provide additional benefits of the IST mechanism, in particular if it has a redistributive character by spreading individual losses over the general farm population (see e.g. Meuwissen et al., 2008, Matthews, 2010). To our knowledge, however, quantification and empirical tests of this effect are not available in the literature. Such information will be of importance for policy makers deciding on the introduction, design and support of IST in European agriculture. In this note, we aim to fill this gap by investigating the impact of an income insurance scheme on income inequality using the example of Swiss agriculture. Furthermore, we account for different designs with respect to the arrangement of farmers' contribution to the costs of the IST.

\section{Method and Data}

We use a balanced farm-level income data set from 1274 Swiss farms covering the period 20032009. Our analysis is based on farm income defined as the sum of farm revenues minus fixed and variable input costs, depreciation, wages, rents and interests and aimed to compensate family labour and equity (see Hausheer Schnider, 2011 for details). We follow the proposal of the European Commission ${ }^{3}$ (EC, 2011) and assume the insurance to indemnify a farmer if he experiences an income loss of more than $30 \%$ compared to the Olympic average of the preceding five-year income realizations $\bar{I}_{O}$. This value represents the reference income $I_{R}=$

\footnotetext{
${ }^{2}$ In fact, agricultural policy measures can affect income distribution at the farm-level as well as the distribution of incomes across farms. For instance, direct payments in Switzerland have contributed to a reduction of both the variability of farm-level household incomes and household income inequality across farms (El Benni et al., 2012, El Benni and Finger, 2013).

${ }^{3}$ Though Switzerland is not member of the European Union, we assume that an IST would be similar to specifications used in other European countries (El Benni, 2012).
} 
$0.7 \bar{I}_{O}$ that triggers indemnification. Finally, the level of indemnification is defined by $70 \%$ of the divergence between actual income $I_{i}$ and the expected income $\bar{I}_{O}$ : Indemnity $=$ $\left\{\begin{array}{c}0 \text { if } I_{i} \geq I_{R} \\ 0.7\left(\bar{I}_{O}-I_{i}\right) \text { if } I_{i}<I_{R}\end{array}\right\}$.

The EC proposal is that a mutual fund is used to cover the costs of indemnification but the detailed IST design is left to the member states, for instance whether participation should be voluntary or compulsory, and how mutual funds are constructed (Pigeon et al., 2012). We assume compulsory participation in our analysis. To cope with the uncertainty regarding farms contribution to mutual funds, we employ a baseline scenario without any income stabilisation (i), as well as three scenarios how the costs of the IST are covered: ii) Full (100\%) subsidization by the government; iii) $65 \%$ subsidization by the government and the remaining $35 \%$ of the costs (i.e. indemnities) are equally divided across farms ${ }^{4}$; iv) all costs are solely covered by farmers via the mutual fund. We focus on actual costs of the IST and do not specify other costs related to the implementation of the IST that may be reflected in premium loadings as well as potential cost increases for farms due to required adjustments in accounting practices.

To avoid exceptional (e.g. market) conditions of a single year we assess the effect of this income insurance scheme on farm-level income outcomes for the years 2008 and 2009. Farms with negative incomes in either year have been removed from the analysis because negative incomes are usually treated differently in such insurance schemes (e.g. in the Canadian AgriStability programme, Kimura and Anton, 2011) and the EC proposal has not specified how such income developments are handled. In total, 57 farm observations were deleted due to observed negative incomes which resulted in a final dataset containing information from 1217 farms.

Following the proposal of the EC (2011), we use the preceding five years of income realizations to identify the reference income levels that trigger indemnification. The costs of the IST that are used for specification of the scenarios are calculated based on the indemnity payments. Following the four different scenarios presented above we re-calculate income levels for each farm in the two example years. Income inequality within the farm population is assessed by a) Gini coefficients, b) the Theil index (with $\alpha=0$ ) and c) the 80/20 quintile share ratio (the ratio

\footnotetext{
${ }^{4}$ Following the EC (2011) proposal the costs of indemnification are paid via a mutual fund and $65 \%$ of the indemnity payments are covered by the government and $35 \%$ by the farmers. The contribution of each farm to such fund does not have to be uniform but could also be based on expected indemnification at the specific farm (Pigeon et al, 2012). This would cause, however, high data demands to reliably estimate the frequency of catastrophic income situations for each farm, which we were not able to overcome with our rather rich dataset. We thus assume that a more pragmatic approach of equal sharing would be adopted in practice.
} 
of the top and bottom $20 \%$ income percentile). In addition, the $25 \%, 50 \%$ and $75 \%$ quantiles of the income distribution are investigated. We use non-parametric bootstrap $(\mathrm{N}=1000)$ to derive 95\% confidence intervals for the quantiles and inequality measures. In order to test for significant difference across scenarios, we use the 1000 bootstrap samples to conduct pairwise comparisons of inequality measures and income quartiles and to construct confidence intervals that are used to test for significant differences at the 5\% level, specifically comparing outcomes under scenarios ii) to iv) to the baseline scenario i) without IST.

\section{Results and Implications}

We find that the IST mechanism - independent on how much of the costs are covered by the government - significantly reduces the income inequality in the Swiss farm population (Table 1). Comparing, for example, the baseline scenario without IST (scenario i) with incomes under a partially subsidized IST (scenario iii) for the year 2008, we find a decrease in the Gini coefficient (from 0.314 to 0.299 ), a decrease in the Theil index (from 0.170 to 0.155 ) and a decrease in the 80/20 ratio (from 2.69 to 2.56), respectively. The income inequality reducing effect of the IST is found to decrease with increasing contribution of farms to the cost coverage. But, even if farmers do not receive any subsidization for the costs of the IST, a significant decrease in income inequality can be observed for all inequality measures. We find income inequality to be larger in 2009. It is expected that the increase in inequality was particularly caused by a drop in milk prices occurring after the abandonment of the quota regime in the Swiss milk market (Mann and Gairing, 2011), which has not affected the farm population homogeneously. Along these lines, also the relative inequality reducing effect of the IST was found to be larger in this year, as farms with exceptional income losses would have been indemnified.

Our results show that the income inequality reducing effect of the IST is especially caused by a reduction of low income observations in the farm population. The incomes in the $25 \%$ income quantile increase significantly in both years. In contrast, differences with respect the $75 \%$ quantile and the median income between scenarios with and without the IST are much less distinct. Thus, for the Swiss case, the income stabilization tool would reduce income inequality through an upward shift of incomes in the lower tail of the income distribution. This effect may be partially caused by the fact that larger farms (potentially characterized by higher levels of expected incomes) often have better risk-return ratios, i.e. face lower (relative) income risks 
(e.g. Barry et al., 2001, El Benni et al., 2012). Thus, these farms - in contrast to smaller farms with low levels of expected income - might be less likely to receive indemnification by the IST. But, also other determinants are expected to have caused the observed shift in lower income quantiles. Overall, we find only small differences in the income inequality measures between the scenarios, describing different premium specification of the IST in terms of cost coverage by farmers. This is - in our example - especially caused by the relative low 'fair premium' of the IST ranging between 1651 and 3265 CHF per farm for the years 2008 and 2009. Compared to the average farm incomes in Switzerland (Table 1) such amounts of indemnity payments are low and lead to only small changes in income inequality. These low levels of expected indemnities (and fair premiums) are due to the fact that income variability in Swiss agriculture is rather low (El Benni et al., 2012) and only a small number of farms would be actually indemnified under the IST. This also reflects the role of the IST 'as an upper bound of the allocation of public resources to be devoted to crisis management' (dell'Aquila and Cimino, 2012), which is not aiming at frequent indemnification but focusses on (rare) catastrophic events. In summary, we find that the Income Stabilisation Tool could reduce income inequality within the farm population, at least in the Swiss case. While not addressed in the current policy debate, this property of the IST constitutes a value added. This result could also imply that governmental costs for the IST may be covered by using financial resources that are currently used for other policy measures aiming to reduce income inequality.

Our analysis has not accounted for behavioural changes due to presence of the IST, e.g. due to moral hazard, which may cause different income outcomes (see e.g. Roberts et al., 2006, OECD, 2011). To explore this issue further, future research may employ modelling approaches allowing depicting farm-level decision making under the IST (see e.g. Mary et al., 2013, Turvey, 2012) for the entire farm population so that effects on income inequality can be quantified.

\section{Acknowledgement}

This work was supported by the Swiss Federal Office for Agriculture and the Swiss National Science Foundation. We would like to thank the Agroscope Reckenholz-Tanikon Research Station for providing the FADN data and two anonymous reviewers as well as the editor for helpful comments and suggestions. 


\section{References}

Alderman, H. and Haque, T. 'Insurance Against Covariate Shocks', Working paper no. 95, World Bank (2008)

Barry, P.J., Escalante, C.L. and Bard, S.K. (2001), "Economic risk and the structural characteristics of farm businesses", Agricultural Finance Review, Vol. 61 No. 1, pp. 74-86.

BFS 'Landwirtschaftliche Gesamtrechnung - Schätzung 2009', Bundesamt für Statistik (BFS), Neuchâtel, Switzerland (2009).

dell'Aquila C. and Cimino O. 'Stabilization of farm income in the new risk management policy of the EU: a preliminary assessment for Italy through FADN data', Paper presented at the 126th EAAE Seminar: "New challenges for EU agricultural sector and rural areas. Which role for public policy?" (Capri, Italy, 2012).

EC 'Proposal for a Regulation of the European Parliament and of the Council on support for rural development by the European Agricultural Fund for Rural Development (EAFRD)', European Commission, Brussels, COM(2011), 627/3 (2011).

El Benni, N. 'Einkommensrisiko in der Schweizer Landwirtschaft und Risikomanagementinstrumente', Report to the Swiss Federal Office for Agriculture, Bern, Switzerland (2012). https://ext.d-nsbpp.admin.ch/NSBExterneStudien/384/attachment/de/1489.pdf

El Benni, N. and Finger, R. 'The effect of agricultural policy reforms on income inequality in Swiss agriculture - An analysis for valley, hill and mountain regions', Journal of Policy Modeling, Vol. 35, (2013) pp. 638-651.

El Benni, N., Finger, R. and Mann, S. 'Effects of agricultural policy reforms and farm characteristics on income risks in Swiss agriculture', Agricultural Finance Review, Vol. 72, (2012) pp. 301-324.

Hausheer Schnider, J. 'Glossar der Zentralen Auswertung von Buchhaltungsdaten', Research Station Agroscope Reckenholz-Tänikon, Ettenhausen, Switzerland (2011).

Keeney, M. 'The distributional impact of direct payments on Irish farm incomes', Journal of Agricultural Economics, Vol. 51, (2000) pp. 252-263.

Kimura, S. and Anton, J. 'Farm income Stabilization and Risk Management: Some Lessons from Agristability Program in Canada', Paper presented at the International Congress of the European Association of Agricultural Economists, (Zurich, Switzerland, 2011).

Liesivaara P., Myyrae, S. and Jaakkola, A. 'Feasibility of the Income Stabilisation Tool in Finland', Paper presented at the 123rd EAAE Seminar: "Price Volatility and Farm Income Stabilisation-Modelling Outcomes and Assessing Market and Policy Based Responses" (Dublin, Ireland, 2012).

Mary, S., Santini, F. and Boulanger, P. 'An Ex-Ante Assessment of CAP Income Stabilisation Payments using a Farm Household Model', Contributed Paper prepared for presentation at the 87th Annual Conference of the Agricultural Economics Society, (Warwick, United Kingdom, 2013).

Matthews, A. 'Perspectives on Addressing Market Instability and Income Risk for Farmers', Discussion Paper No. 324, Institute for International Integration Studies, Trinity College Dublin, Ireland, 2010.

Meuwissen, M.P., Asseldonk, M.V. and Huirne, R.B. (eds.) Income stabilisation in European agriculture: Design and economic impact of risk management tools. Wageningen, The Netherlands: Wageningen Academic Publishers, 2008. 
Meuwissen M.P.M., van Asseldonk, M., Pietola, K., Hardaker, B. and Huirne, R. 'Income insurance as a risk management tool after 2013 CAP reforms?', paper presented at the EAAE 2011 Congress "Change and Uncertainty” (Zurich, Switzerland, 2011).

OECD,Managing Risk in Agriculture: Policy Assessment and Design, OECD Publishing (2011), doi: 10.1787/9789264116146-en

Pigeon, M., Henry de Frahan, B. and Denuit, M. 'Actuarial evaluation of the EU proposed farm income stabilisation tool', paper presented at the 123rd EAAE Seminar: "Price Volatility and Farm Income Stabilisation-Modelling Outcomes and Assessing Market and Policy Based Responses" (Dublin, Ireland, 2012).

Roberts, M.J., Key, N. and O'Donoghue. E. 'Estimating the extent of moral hazard in crop insurance using administrative data.' Applied Economic Perspectives and Policy Vol. 28 (2006) pp. 381-390.

Turvey, C.G. 'Whole farm income insurance', Journal of Risk and Insurance, Vol. 79, (2012) pp. 515-540.

Turvey, C.G. and Kong, R. 'Weather risk and the viability of weather insurance in China's Gansu, Shaanxi, and Henan provinces', China Agricultural Economic Review, Vol. 2 (2010) pp. 5-24. 
Table 1. Effects of IST on income quartiles and Gini coefficients.

\begin{tabular}{|c|c|c|c|c|c|c|c|c|c|c|c|c|}
\hline & & & & \multicolumn{3}{|c|}{2008} & & & \multicolumn{4}{|c|}{2009} \\
\hline & & & & \multicolumn{3}{|c|}{$\begin{array}{l}\text { Quantiles of the income } \\
\text { distribution }\end{array}$} & & & & \multicolumn{3}{|c|}{$\begin{array}{l}\text { Quantiles of the income } \\
\text { distribution }\end{array}$} \\
\hline Scenario & $\begin{array}{l}\text { Gini } \\
\text { coefficient }\end{array}$ & Theil & $\begin{array}{l}80 / 20 \\
\text { ratio }\end{array}$ & $25 \%$ & $50 \%$ & $75 \%$ & $\begin{array}{l}\text { Gini } \\
\text { coefficient }\end{array}$ & Theil & $\begin{array}{l}80 / 20 \\
\text { ratio }\end{array}$ & $25 \%$ & $50 \%$ & $75 \%$ \\
\hline i) No insurance & $\begin{array}{l}0.314 \\
{[0.299-} \\
0.331]\end{array}$ & $\begin{array}{l}0.170 \\
{[0.148-} \\
0.204]\end{array}$ & $\begin{array}{l}2.69 \\
{[2.55-} \\
2.85]\end{array}$ & $\begin{array}{l}43953 \\
{[41424-} \\
47066]\end{array}$ & $\begin{array}{l}66266 \\
{[63482-} \\
68858]\end{array}$ & $\begin{array}{l}96186 \\
{[92020-} \\
100729]\end{array}$ & $\begin{array}{l}0.327 \\
{[0.314-} \\
0.341]\end{array}$ & $\begin{array}{l}0.178 \\
{[0.163-} \\
0.193]\end{array}$ & $\begin{array}{l}2.83 \\
{[2.66-} \\
3.05]\end{array}$ & $\begin{array}{l}37092 \\
{[34973-} \\
39176]\end{array}$ & $\begin{array}{l}60178 \\
{[56913-} \\
62371]\end{array}$ & $\begin{array}{l}85561 \\
{[83064-} \\
88301]\end{array}$ \\
\hline $\begin{array}{l}\text { ii) Fully } \\
\text { subsidized by } \\
\text { government }\end{array}$ & $\begin{array}{l}0.297 \\
{[0.283-} \\
0.315]^{*}\end{array}$ & $\begin{array}{l}0.153 \\
{[0.131-} \\
0.186]^{*}\end{array}$ & $\begin{array}{l}2.54 \\
{[2.39-} \\
2.70]^{*}\end{array}$ & $\begin{array}{l}47308 \\
{[44247-} \\
49232]^{*}\end{array}$ & $\begin{array}{l}67169 \\
{[64376-} \\
69461]^{*}\end{array}$ & $\begin{array}{l}96575 \\
{[92362-} \\
101321]\end{array}$ & $\begin{array}{l}0.292 \\
{[0.279-} \\
0.304]^{*}\end{array}$ & $\begin{array}{l}0.139 \\
{[0.128-} \\
0.152]^{*}\end{array}$ & $\begin{array}{l}2.50 \\
{[2.35-} \\
2.65]^{*}\end{array}$ & $\begin{array}{l}42920 \\
{[40077-} \\
44917]^{*}\end{array}$ & $\begin{array}{l}62371 \\
{[60453-} \\
64140]^{*}\end{array}$ & $\begin{array}{l}86644 \\
{[84292-} \\
90563]^{*}\end{array}$ \\
\hline $\begin{array}{l}\text { iii) Part } \\
\text { premium }(65 \% \\
\text { subsidized by } \\
\text { government, } \\
35 \% \text { paid by } \\
\text { farmers) }\end{array}$ & $\begin{array}{l}0.299 \\
{[0.285-} \\
0.317]^{*}\end{array}$ & $\begin{array}{l}0.155 \\
{[0.133-} \\
0.188]^{*}\end{array}$ & $\begin{array}{l}2.56 \\
{[2.40-} \\
2.72]^{*}\end{array}$ & $\begin{array}{l}46794 \\
{[43660-} \\
48763]^{*}\end{array}$ & $\begin{array}{l}66604 \\
{[63859-} \\
68989]\end{array}$ & $\begin{array}{l}95999 \\
{[91825-} \\
100751]\end{array}$ & $\begin{array}{l}0.297 \\
{[0.284-} \\
0.309]^{*}\end{array}$ & $\begin{array}{l}0.145 \\
{[0.132-} \\
0.158]^{*}\end{array}$ & $\begin{array}{l}2.54 \\
{[2.39-} \\
2.71]^{*}\end{array}$ & $\begin{array}{l}41821 \\
{[38952-} \\
43785]^{*}\end{array}$ & $\begin{array}{l}61205 \\
{[59183-} \\
62983]^{*}\end{array}$ & $\begin{array}{l}85517 \\
{[83139-} \\
89434]\end{array}$ \\
\hline $\begin{array}{l}\text { iv) Full } \\
\text { premium paid } \\
\text { by farmers }\end{array}$ & $\begin{array}{l}0.304 \\
{[0.289-} \\
0.321]^{*}\end{array}$ & $\begin{array}{l}0.159 \\
{[0.137-} \\
0.194]^{*}\end{array}$ & $\begin{array}{l}2.59 \\
{[2.44-} \\
2.77]^{*}\end{array}$ & $\begin{array}{l}45790 \\
{[42618-} \\
47818]^{*}\end{array}$ & $\begin{array}{l}65591 \\
{[62898-} \\
68112]\end{array}$ & $\begin{array}{l}95020 \\
{[90883-} \\
99859]\end{array}$ & $\begin{array}{l}0.306 \\
{[0.293-} \\
0.319]^{*}\end{array}$ & $\begin{array}{l}0.155 \\
{[0.142-} \\
0.170]^{*}\end{array}$ & $\begin{array}{l}2.64 \\
{[2.48-} \\
2.82]^{*}\end{array}$ & $\begin{array}{l}39689 \\
{[36903-} \\
41745]^{*}\end{array}$ & $\begin{array}{l}59109 \\
{[56915-} \\
60890]^{*}\end{array}$ & $\begin{array}{l}83409 \\
{[80840-} \\
87415]^{*}\end{array}$ \\
\hline
\end{tabular}

Numbers in parentheses depict $95 \%$ confidence intervals. * indicates that difference to the 'no insurance' scenario i) is significant at the 5\% level. 